特集記事 ワークショップ報告

次世代の遺伝学と育種 I

高橋 有 ${ }^{1,2}$ ・ 山内卓樹 2,3) ・ 内藤 健 ${ }^{1,4)}$ ・森田裕将 5,8$)$ ・安達俊輔 $\left.1,4,9\right)$ ・高木宏樹 6,7)

1) 農業生物資源研究所, 茨城県つくば市, 干 305-8602

2) 日本学術振興会, 特別研究員 PD

3) 名古屋大学大学院生命農学研究科, 愛知県名古屋市, $=464-8601$

4) 科学技術振興機構, さきがけ, 埼玉県川口市, テ332-0012

5) 香川大学農学部, 香川県三木町, 干 761-0795

6) 岩手生物工学研究センター, 岩手県北上市, 干 024-0003

7) 岩手大学大学院連合農学研究科, 岩手県盛岡市, 干 020-8550

8) 現 : 名城大学農学部附属農場, 愛知県春日井市, $\bar{T} 486-0804$

9) 現：農研機構作物研究所, 茨城県つくば市, 干 305-8518

\title{
Genetics and breeding for next generation II
}

Yu Takahashi ${ }^{1,2)}$, Takaki Yamauchi ${ }^{2,3)}$, Ken Naito ${ }^{1,4)}$, Yasumasa Morita ${ }^{5,8)}$, Shunsuke Adachi ${ }^{1,4,9)}$ and Hiroki Takagi ${ }^{6,7)}$

1) National Institute of Agrobiological Sciences, Tsukuba, Ibaraki 305-8602

2) Research Fellow of the Japan Society for the Promotion of Science

3) Graduate School of Bioagricultural Sciences, Nagoya University, Nagoya, Aichi 464-8601

4) Japan Science and Technology Agency, PRESTO, Kawaguchi, Saitama 332-0012

5) Faculty of Agriculture, Kagawa University, Miki, Kagawa 761-0795

6) Iwate Biotechnology Research Center, Kitakami, Iwate 024-0003

7) United Graduate School of Iwate University, Morioka, Iwate 020-8550

8) Present address: Experimental Farm, Faculty of Agriculture, Meijo University, Kasugai, Aichi 486-0804

9) Present address: NARO Institute of Crop Science, Tsukuba, Ibaraki 305-8518

キーワード

花色制御，個葉光合成速度，次世代シーケンサー

\section{はじめに}

本稿は日本育種学会第 124 回講演会で開催されたワー クショップのセッション「次世代の遺伝学と育種 $2 」$ の 講演内容を簡潔にまとめたものである. 同セッションは, 著者ら（高橋，山内，内藤）が代表を務める日本育種学 会若手の会により企画された。同若手の会は, 日本育種 学会の一般会員叔よび学生会員で構成されており, これ までにも日本育種学会講演会に扎いてワークショップあ るいはグループ研究集会を企画している。そ爰的は, 1）若手研究者同士が交流し, 親しくなることで, 現在あ るいは将来の研究協力や人材交換が容易飞行兄るような 関係を準備すること，2）現在進行中の先駆的な研究につ いて情報を提供し合い，気軽に（時に熱く）議論する場 を提供することである（高橋ら 2013）。ワークショップ

2013 年 12 月 16 日受領

Correspondence: takahashi0126@affrc.go.jp;

atkyama@agr.nagoya-u.ac.jp; knaito@affrc.go.jp
とは本来, 一方的な知の伝達でなく, 聴衆が自ら参加あ るいは体験する双方的な学びと創造のスタイルである。 これを踏まえて，同セッション企画にあたっては上述の 目的 2）を重んじた。それを達成するには, 話題提供者 の研究が魅力的で且つ発表の構成が的確であり, 聴衆の 興味を十分に引き出す必要がある。 そこで, 同セッショ ンでは，日本育種学会員に限らず各分野で活躍している 若手研究者 3 名を話題提供者として招聘した. 香川大学 の森田裕将氏には，アサガオやペチュニアなど花き園芸 植物の花色制御機構について, 農業生物資源研究所の安 達俊輔氏には, イネ光合成速度の遺伝的改良を目指した 研究について, 岩手生物工学研究センタ一の高木宏樹氏 には，次世代シーケンサーを用いた突然変異体の原因遺 伝子の新規同定法について講演頂いた。 以下は話題提供 者が講演内容をまとめたものであり, 本稿の読者が研究 に取り組む上で参考になることを期待したい. 
演題 1 花き園芸植物研究から明らかになった花色制御 機構

\section{森田裕将（香川大学農学部）}

花き園芸植物の多彩な花の色調や多様な模様は，育種 や品種改良によって生久出されて来た．本項では，1）突 然変異育種によって改良が進んだアサガオと，2）種間雑 種育種により多くの品種が作出されたペチュニアの花色 研究から得られた最近の知見を報告する.

\section{1. アサガオ花色と突然変異育種}

アサガオ (Ipomoea nil) は，日本の夏の風物詩として 親しみの深い花き園芸植物である.八世紀頃中国よりも たらされたアサガオは，青色の花を咲かせたと考えられ ている。これまで続く栽培の歴史の中で, 種々の花色や 花形, 草姿形成に関わる突然变異が単離され, 育種・品 種改良に用いられてきた。近年の分子遺伝学的な解析か ら，これらの突然変異とゲノム内を移動するトランスポ ゾンとの関係が明らかになっている. 基礎生物学研究所 の研究グループでは, 市販されるアサガオ品種系統から トランスポゾンの転移が観察される個体（図 1a）を分離 した後，薄い色調の花弁に濃色のキメラ斑を持つ易変性 の突然変異体 efp-1（図 1b）を得た。 これは, 現在のア サガオ栽培品種においてもトランスポゾンによって新た な突然変異が得られることを示す。これまでの解析から， $E F P$ 遺伝子は，花色素アントシンアニンを含むフラボノ イド化合物の生合成量を制御する新規タンパク質をコー ドすることを示す結果を得ている.トウモロコシやペチュ
ニア，キンギョソウ，アラビドプシスなどのフラボノイ ド研究の長い歴史, 近年の解析技術の進歩や配列情報が 蓄積される状況の中, クラシカルな遺伝学的手法を基に, 日本の古典園芸植物であるアサガオより新規な成果が得 られたことは感慨深い。

多彩な花色に加えて, 多様な花の模様は, 花き園芸植 物の大きな魅力である，花弁に生じる模様は，遺伝子発 現の指標となると共に, 模様発現に寄与している変異に 興味が持たれる. 刷毛目絞 (duskish-mutable) 変異体は, 刷毛で引いた様な模様を花弁に生じる（図 1c). 刷毛目 模様は，トランスポゾンの脱離により生じるセクター状 のキメラ斑（図 $1 \mathrm{a}, \mathrm{b}, \mathrm{d}$ ） とは大きく異なって扣り，模様 形成機構の違いが予想された。連鎖地図情報を基に原因 遺伝子と変異の同定を試みたところ，アントシアニン合 成に関わる配糖化酵素遺伝子のプロモーター上流にトラ ンスポゾンの挿入を見出した。 興味深い事に, 刷毛目絞 花弁の有色組織および, 刷毛目絞個体から分離される復 帰系統の有色花弁では, 原因遺伝子が発現しているにも 関わらずトランスポゾンの脱離は観察されなかった。一 方で，刷毛目絞個体から分離した刷毛目模様を持たない 変異体系統では, トランスポゾンの脱離を伴ったキメラ 斑が花弁に生じ（図 1d）, この系統からは, トランスポ ゾンの脱離による生殖細胞復帰個体が得られることを見 出した. 原因遺伝子のプロモーター上流に存在するトラ ンスポゾンが不活性化する場合には刷毛目模様が生じ, 活性化する場合には刷毛目模様の形成が抑制される代わ りに，キメラ斑が生じるよらである。トランスポゾンな

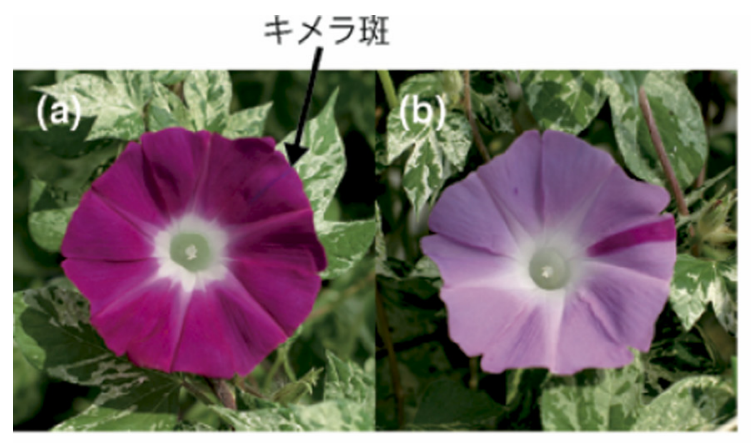

EFP

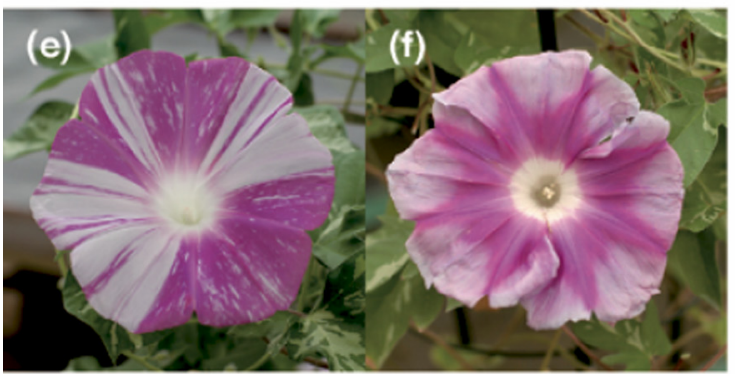

Blizzard 吹雪
Rayed 車絞

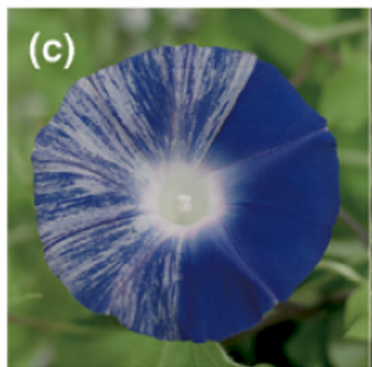

duskish-mutable 刷毛目絞

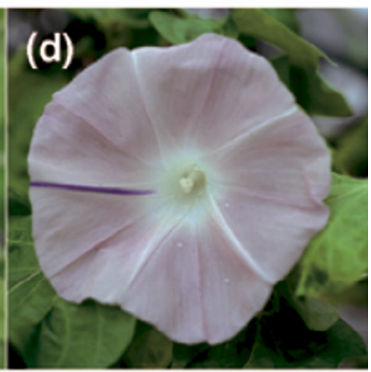

duskish-mutable キメラ斑

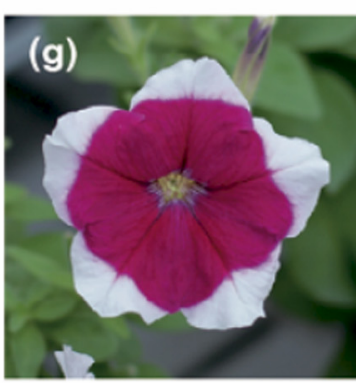

Picotee (h)

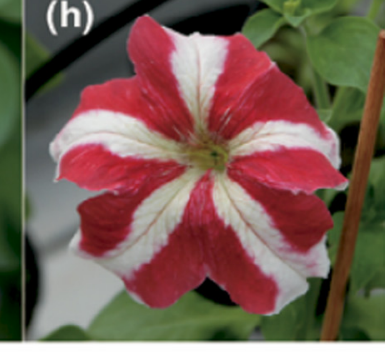

Star

図 1.アサガオとペチュニアの花弁に生じる多様な形質 
ぞ，ゲノム内に存在する反復配列は，エピジェネティッ クな修飾の対象になりやすい，アサガオの刷毛目模様は, トランスポゾンの転移頻度に関わるエピジェネティック な修飾状態の変化が，近傍遺伝子の発現に影響を及ぼす ことを示す好例であると考光ている，バラ，カーネーショ ン, トルコギキョウなどの主要な花き品目にも易変性が 散見されることから，活発に転移する（過去に転移活性 を有した）トランスポゾンが園芸植物の花色や模様の多 様化の一因になっているかもしれない.

我々の研究グループでは，RNA干渉により生じた斑入 り模様の解析も併せて進めている. RNA 干渉が関与する 花の模様研究は, 導入遺伝子と内在遺伝子の発現が共に 抑制されるコサプレッションによりペチュニアの形質転 換植物花弁に生じた白色の斑入り模様に遡ることができ る (Napoli et al. 1990). 類似の模様は, 花き園芸植物に 散見され，最近では，RNA 干渉によるダリア品種の模様 形成や花色変異の例が報告されている（Ohno et al. 2011， Deguchi et al. 2013）。しかしながら，RNA 干渉に必要な ゲノム構造など詳細な研究結果は，後述するペチュニア の解析例に限られている。 また, 最も興味が持たれる花 弁の特定の領域でのみ RNA 干渉が引き起こされる機構 は, 現在も不明な点が多い.アサガオの吹雪 (Blizzard) と車絞 (Rayed) は, 有色の花弁に白色の斑を生じる（図 $1 \mathrm{e}, \mathrm{f})$. これらの模様は大きく異なるが，その原因は花色 遺伝子の遺伝子重複に起因した同一の反復構造により引 き起こされるRNA 干渉であることが見出された。これ までに，吹雪と車絞の花弁で蓄積している低分子 RNA の網羅的な解析から，2つの変異体では反復領域に起因 する低分子 RNA のサイズや種類の違いを示す結果を得 ている. 反復領域に起因する低分子 RNA の産生機構の 解析を通して, 吹雪と車絞の模様を生じさせる部位特異 的な RNA 干渉の制御機構を明らかにしていきたい.

\section{2. ペチュニア花色と種間雑種育種}

ペチュニア（Petunia hybrida）園芸品種は，野生種の種 間交雑により多くの形質が付与されてきた。今回報告を 行ったPicotee とStar タイプの模様（図 1g, h) は, 1800 年代に行わ机た種間雑種育種によって生じたことが Bailey の著書 The Survival of the Unlike（1896）に記述さ れる. 先行していた Star タイプの研究から, 白色花弁組 織で特異的に作られる花色遺伝子 CHS-A の配列を持った 低分子 RNA により誘導される $C H S-A$ 遺伝子の RNA 干 渉が，模様形成の原因であると示されていた（Koseki et al. 2005). 花き研究所を中心とする研究グループの更な る解析により, 模様の異なる Picotee と Star タイプの模 様形成には, 1) 2 つ CHS-A 遺伝子 PhCHS-A1 と PhCHS$A 2$ が順方向にならぶ同一のタンデム構造が必要であるこ と，2）2つの $C H S-A$ 遺伝子の第 2 エクソンに由来する $C H S-A$ 低分子 RNA が白色の組織特異的に産生されるこ と, 3) PhCHS-A1 と PhCHS-A2 から転写される mRNA の
分解が白色の組織特異的に起きていることが明らかに なった（Morita et al. 2012）。また，野生種 $C H S$ - $A$ 遺伝子 配列の解析から, 品種形成に寄与した 3 種の野生種 $P$. axillaris, P. integrifolia, P. inflata の内, Picotee/Star 品種 のCHS-A のゲノム構造の形成には, P. inflata の関与を示 唆する結果を得ている. Picotee と Star 花弁の白色組織特 異的に, PhCHS-A1 と PhCHS-A2 より CHS-A 低分子 RNA が産生される機構に興味が持たれる。

アサガオとペチュニアの花色研究から，トランスポゾ ンが関与する花の模様や，遺伝子の重複構造を介して花 弁の特定の部分で RNA 干渉を誘導する機構の存在が明 らかになってきた。花き園芸植物の多様な花色や模様の 解析が進展し, 今後明らかになる分子機構のことを想像 すると胸の高鳴りを覚光る.

\section{演題 2 自然変異の利用によるイネ個葉光合成速度の遺 伝的改良}

安達俊輔 1,2 (1. 農業生物資源研究所，2. 日本学術振興 会特別研究員 PD)

増加の一途をたどるアジアの人口を支えていくために, 主食であるコメの生産量の一層の増加が求められている. 今後栽培面積の拡大は望めないことから，生産量を増加 させるためには単位土地面積当たり子実収量の向上が不 可欠であると言わ秃ている（Mann 1999）。イネ子実収量 向上のためには, 同化産物の貯蔵能力（シンク能）とそ の供給能力（ソース能）の両者を同時に高めていくこと が必要である. シンク能改良に関わる遺伝子はこれまで 多数報告がある一方で, ソース能改良に関わる遺伝子の 報告はほとんどなく，その解明が待たれている (Yamamoto et al. 2009). 本項ではイネンース能改良の鍵である個葉 光合成速度の遺伝的改良を目指した筆者らの試みを紹介 する（図 2)。

\section{1. 個葉光合成速度に関わる遺伝子のマップベースクロー ニング}

個葉光合成速度（以下，光合成速度）は多くの場合， 大気 $\mathrm{CO}_{2}$ 濃度条件下に㨟いて葉面積当たり $\mathrm{CO}_{2}$ 吸収速 度で表される。光合成速度は植物体のエイジや外環境に よって大きな影響を受けるが，測定時期や時刻を考慮し， 測定環境を一定にすることによって精度の良い測定が可 能となる，筆者らは登熟に最も大きく影響する止葉に着 目し, 光合成速度が最大に達する出穂直後の時期に, そ して 1 日のらちで最も光合成速度が高い午前の時間帯に, 同化箱内環境条件を高精度に制御できる LI-COR 社の LI-6400 装置を用いて光合成速度を評価し，その原因遺伝 子の特定を目指した。インド型多収性品種ハバタキは, 出穂直後の時期には他の多くのアジアの品種の中で最も 高い光合成速度を示すことから，光合成能力改良のため の有用な育種素材と考光られる（浅沼ら 2008）。そこで 八バタキと光合成速度が低いコシヒカリに由来する組換 


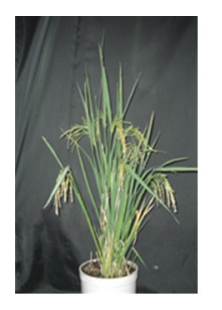

タカナリ 高い葉身窒素含量 高い気孔伝導度 厚い葉肉組織

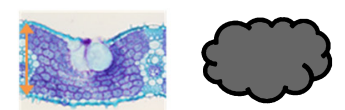

コシヒカリ

サイズが小さく突起の 発達した葉肉細胞
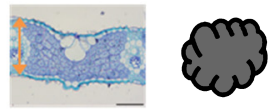
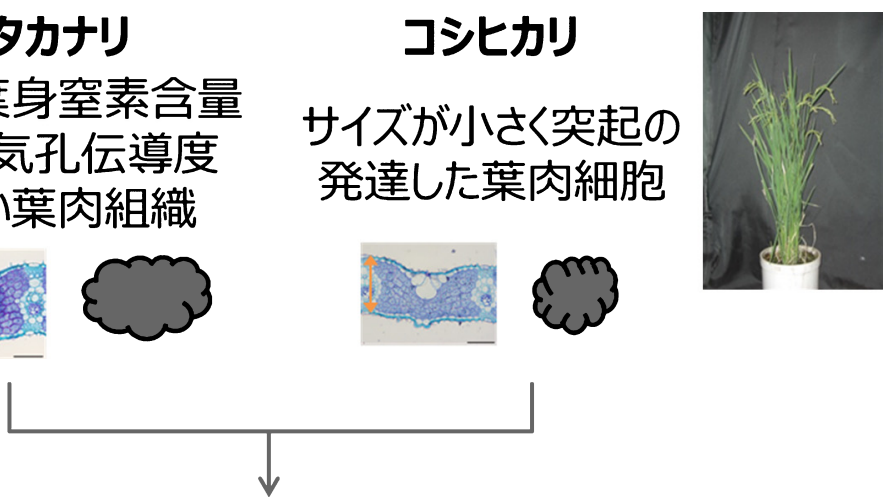

遺伝子座の同定と機能解明および集積

トウモロコシに匹敵する高い光合成能力を有するイネの育成

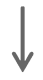

高収量・高バイオマスイネの育成

研究成果の他作物への応用

図 2. イネ個葉光合成速度の飛躍的改良に向けた研究戦略と応用

光固定系統を育成し，その形質評価を通じてハバタキ対 立遺伝子が光合成速度を高める染色体領域を第 $4 ， 5 ， 8$, 11 染色体上飞見出した（Adachi et al. 2011）。このらち第 8 染色体についてさらに絞り込みを行い, 原因遺伝子 CARBON ASSIMILATION RATE 8（CAR8）を特定した. こ の遺伝子は気孔開度の上昇効果を持ち, 大気から葉内一 の $\mathrm{CO}_{2}$ 拡散を促進することによって光合成速度を高める ものと推察された。また第 4 染色体領域については, 八 バタキの姉妹品種で同様に高い光合成速度を示すタカナ リとコシヒカリの組換え固定系統を用いて，原因遺伝子 GREEN FOR PHOTOSYNTHESIS (GPS) を特定した（Takai et al. 2013). この遺伝子は葉の形態に関わるとされる既 知遺伝子 NARROW LEAF 1 の变異型で, 葉面積当たり葉 肉細胞数を増加させ，光合成酵素量の増加を通じて光合 成速度を高めるものと推察された。ささらにCAR8 打よび $G P S$ を含むハバタキ領域を集積させたコシヒカリ系統 は，両遺伝子の優れた性質を併せ持つことにより一層高 い光合成速度を示した，以上の研究成果は，これまで意 図的には行われてこなかった光合成速度の遺伝的改良が 今後のイネ育種戦略となりらることを示している，筆者 らは上述のように GPS, CAR 8 以外の領域飞も光合成速 度に関わる染色体領域を見出して和り, そ和ら遺伝子の 特定敃よび集積によって光合成速度を一層高められる可 能性がある.

\section{2. 個葉光合成速度の飛躍的な改良の可能性}

高い光合成速度を示すハバタキ・タカナリのゲノムを 活用することによってコシヒカリの光合成速度を高める ことだけでなく、コシヒカリゲノムを活用することによっ
てこれらインド型品種の光合成速度を大幅に高められる 可能性がある、筆者らはタカナリとコシヒカリの戻し交 雑自殖系統群 $\left(\mathrm{BC}_{1} \mathrm{~F}_{6}\right)$ の中に, タカナリの光合成速度を 大幅に上回り， $\mathrm{C}_{4}$ 植物のトウモロコシにも匹敵する高い 光合成速度を示すイネ系統 (HP 系統) を見出した (Adachi et al. 2013). HP 系統はタカナリと比較して光合成酵素量 と気孔伝導度には浮とんぞ違いがないが，細胞間隙から 葉緑体に至る $\mathrm{CO}_{2}$ 拡散効率の指標である葉肉伝導度がタ カナリに比べ有意に高くなっていた。また HP 系統は夕 カナリに由来する葉が厚い性質に加え, コシヒカリに由 来するサイズが小さく発達した突起を持つ細胞形態を併 せ持つことによって葉肉伝導度が上昇し, 著しく高い光 合成速度を発揮したと推察された，以上のように，光合 成速度が高くはない品種でも光合成改良に有利な性質を 有して拉り, このことは他種植物からの遺伝子導入や野 生稲などの遺伝資源に頼らなくても既存のイネ品種が持 つ遺伝子の活用によって光合成速度の飛躍的な向上が可 能であることを示している。筆者らは現在コシヒカリが 持つ有用遺伝子についてもそのクローニングに向け検討 を進めている。，ハバタキ・タカナリ，そしてコシヒカリ の持つ有用遺伝子の探索とその適切な利用を通じて, 様々 なイネ品種の光合成速度ひいてはイネ収量の飛躍的向上 に貢献したいと考兄ている(図 2).

演題 3 MutMap, MutMap+ \& MutMap-Gap: 次世代 シーケンサーを用いた遺伝子単離技術

高木宏樹 ${ }^{1,2}$, 八重樫弘樹 ${ }^{1}$, 植村亜衣子 ${ }^{1}$, 宇津志博恵 ${ }^{1}$, 夏目 俊 ${ }^{1,2}$, 阿部 陽 ${ }^{1}$, 寺内良平 ${ }^{1,2}$ (1. 岩手生物工学 研究センター, 2. 岩手大院連合農学) 
近年, 次世代シーケンサー技術の進展により，全ゲノ ム配列解読が完了した様々な生物種において, ゲノム中 の変異箇所を網羅的に解析する技術の開発が進んでいる. そのような技術の1つとして，著者らは，MutMap 法を 開発し, 次世代シーケンサーを用いて迅速に突然変異体 の原因遺伝子を同定することに成功した（Abe et al. 2012).MutMap 法では，まず，突然変異体とその変異体 の原品種を交配して F2 世代を育成する。次に，F2 世代 の中から変異体型を示す個体を選抜し，バルク DNAを 作製する．最後にバルク DNAを全ゲノムシーケンスし て全ゲノム領域にわたって SNP-index 值 (Abe et al. 2012）を計算し，SNP-index が 1 を示す領域から原因突 然変異を同定する方法である (図 3a)。これまで, 著者 らはMutMap 法を用いて多くの遺伝子単離に成功してき たが，研究を進める中でMutMap 法を直接適用できない 場面に直面した。本項では，MutMap 法を適用できない 状沉を克服する新規手法として MutMap-Gap 法（図 3b） 扣よびMutMap+法（図 3c）について紹介する.

\section{MutMap-Gap 法}

MutMap 法は，リシーケンスを基盤とした技術である.

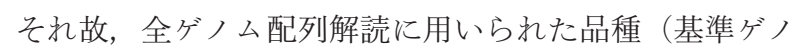
ム：イネでは「日本晴」）とは異なる品種（例；イネでは 「コシヒカリ」や「ひとめぼれ」）を用いた場合，その品 種特異的なゲノム領域ではシーケンス結果のアライメン トが正確にできないため, このような領域に生じた変異
の検出ができなかった，そこで，リシーケンスと de novo アッセンブリを併用した新規手法として MutMap-Gap 法 を確立した（Takagi et al. 2013a）。

MutMap-Gap 法の原理は, 次の通りである. (1)変異体 の原品種のゲノムをシーケンスし, 基準ゲノム配列に対 してアライメントし (リシーケンス), 原品種の基準配列

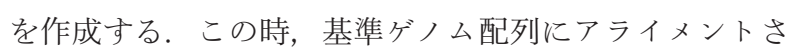
れなかったショートリード群をアンマップリードとして 別に保存する。（2)目的と寸る変異体を選抜後，原品種の 基準配列を用いた MutMap 法により，原因遺伝子が座上 する大まかなゲノム領域を特定する。 (3)MutMap 法で特 定された候補領域内にアライメントされたショートリー ド拉よび上記(1)のアンマップリードを用いて de novo アッ センブリを行い, コンティグを構築する。このステップ は，候補領域内のゲノム配列を de novo アッセンブリに より再構築することを意味する. (4)最後に, 構築された コンティグに対して, 再度 MutMap 解析を行い, 変異形 質の原因変異を同定する.

MutMap-Gap 法を適用することにより，全ゲノム配列 解読が完了した生物種であれば，解読に用いた品種とは 異なる品種に扔いてもリシーケンス技術による变異解析 が容易になった。

\section{MutMap+法}

MutMap 法では，まず，突然変異体とその変異体の原 品種を交配して F2 世代を育成する必要がある。それ故, (a)

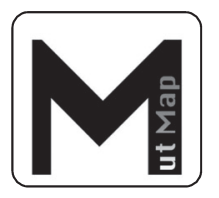

$\mathrm{F} 2$ 世代の育成

親系統

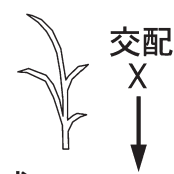

变異体型
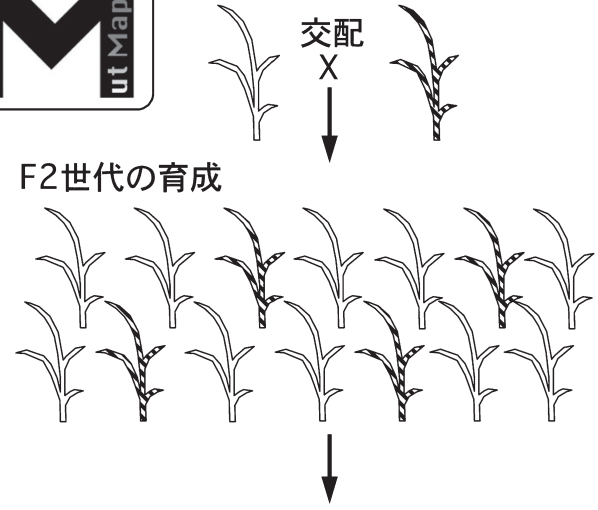

F2 世代の中から変異体型を選抜し、全ゲノム シーケンスによる解析へ

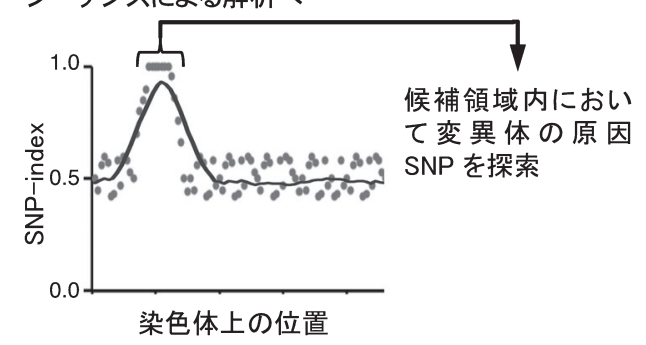

(b)

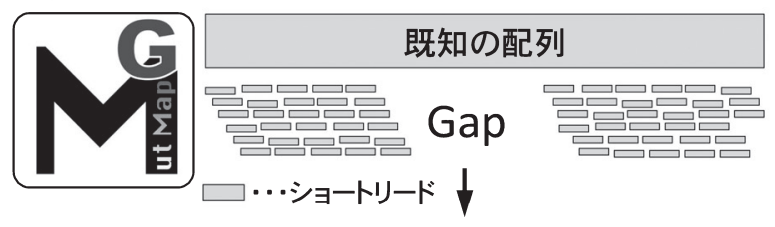

全ゲノム解読に用いられた品種と異なる品種をリシーケンスし た場合、ゲノム構造が大きく違う領域では、ショートリードがアラ イメントされない(Gap 領域)。

de novo assemble を併用する

(c)

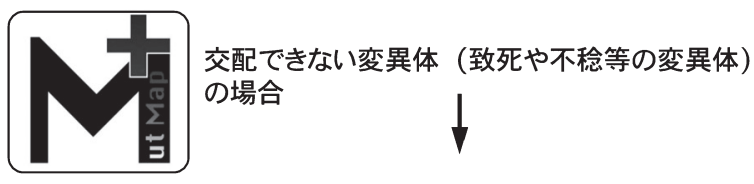

分離を示す1個体由来の自殖後代において変異体型と野生 型を示す個体のバルクDNA をそれぞれ解析し、比較する

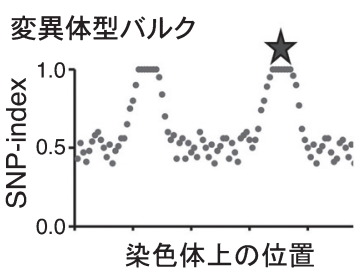

野生型バルク

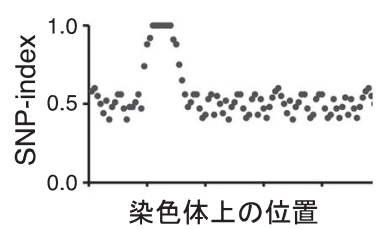

図 3. MutMap シリーズ : (a) MutMap 法, （b）MutMap-Gap 法, (c) MutMap+法 
MutMap 法は, 交配が難しい変異体や植物種への適用が 困難であった。例えば，幼苗期致死変異体や不稔を示す 変異体では交配ができないため, MutMap 法を用いた遺 伝子単離に問題があった。 そこで，交配過程を経ず，突 然変異体の自殖後代の分離集団を用いた新規手法として MutMap+法を確立した（Fekih et al. 2013）.

MutMap+法の原理は次の通りである. (1)原因突然変異 をへテロで保有する個体の自殖後代において，変異体型 と野生型が分離する場合, 変異体型と野生型をそれぞれ 20 個体以上選抜する。(2)選抜した個体からそれぞれバル ク DNA を作製し, MutMap 解析に供試する。(3)変異体型 バルク DNA および野生型バルク DNA の MutMap 解析後 に共通の SNP についてそれぞれの SNP-index 值を計算す る. (4)変異体型バルク DNA および野生型バルク DNAの SNP-index を比較し, 前者の SNP-index が後者の SNPindex より有意に高いSNPを検出することで原因遺伝子 を同定する。

MutMap+法では，上記(1)のように交配過程が不要であ る。そのため，交配が困難な植物種にも適用できる。ま た，野生型バルク DNAの解析結果を内部標準として利 用しているので, 解析の精度も MutMap 法と比較して向 上した。

これまで，著者らは，上記のように人為的な突然変異 体に打ける遺伝子単離法（MutMap 法, MutMap-Gap 法, MutMap+法）を中心に開発してきた。現在，岩手県で は, イネの育種現場において MutMap シリーズを用いて 突然変異体の原因遺伝子を同定して，その遺伝子を品種 育成に利用している。一方，自然変異の利用も重要であ る. 1 世代に人為的に誘発する突然変異と比較して, 長 い年月をかけてその生物が蓄積してきた自然変異は，自 然和よび人為選択を受けて選抜された変異も含まれるた め, 有用な allele を多く含む. 著者らは, MutMap シリー ズを開発してきた経験を生かし，QTL-seq 法（Takagi et al. 2013b）をはじめ, 次世代シーケンサーを用いて自然 変異を迅速に同定する手法の確立にも取り組んでいる.

\section{おわりに}

当日は大変多くの方々にご参加頂いた．若手研究者や 学生に加えて著名なべテラン研究者にもご参加頂いたこ とは企画者らにとって大変嬉しいことであった。 そのよ らな中で, フリーディスカッション形式を採用した質疑 応答の時間には，科学的論証の正当性や今後の展望につ いて非常に活発な議論が交わされた。 それは, 話題提供 者の研究が魅力的で且つ発表の構成が的確であり, 聴衆 の興味を十分に引き出した結果であったと言える，終了 後には，「同世代の活躍に触発されました」「とても勉強 になりました」なぞ賞賛の声を頂き，ワークショップを 継続する意義を感じ取ることができた.

日本育種学会若手の会ではメーリングリストを作成し
ており, 論文・求人などの情報交換および研究会の話題 提供者募集・開催予告などに利用している。本稿の読者 も是非, 定例の研究会和よびメーリングリストに参加し て我々と議論を交わして頂きたい.メーリングリストは 野菜茶業研究所の宮武宏治が管理しており, 参加希望の 方は以下のアドレスまでご連絡を頂きたい (miya0424@affrc.go.jp).

\section{謝 辞}

会場を提供してくださった大会運営委員会の先生方和 よび会場スタッフの方々には大変お世話になった。 また, 開催準備を手伝って頂いた日本育種学会若手の会の皆様 およびワークショップに参加して頂いた方々にも深く感 謝の意を申し上げる.

\section{引用文献}

Abe, A., S. Kosugi, K. Yoshida, S. Natsume, H. Takagi, H. Kanzaki, H. Matsumura, K. Yoshida, C. Mitsuoka, M. Tamiru et al. (2012) Genome sequencing reveals agronomically important loci in rice using MutMap. Nat. Biotechnol. 30: 174-178.

Adachi, S., T. Nakae, M. Uchida, K. Soda, T. Takai, T. Oi, T. Yamamoto, T. Ookawa. H. Miyake, M. Yano et al. (2013) The mesophyll anatomy enhancing $\mathrm{CO}_{2}$ diffusion is a key trait for improving rice photosynthesis. J. Exp. Bot. 64: 1061-1072.

Adachi, S., Y. Tsuru, N. Nito, K. Murata, T. Yamamoto, T. Ebitani, T. Ookawa and T. Hirasawa (2011) Identification and characterization of genomic regions on chromosomes 4 and 8 that control the rate of photosynthesis in rice leaves. J. Exp. Bot. 62: 1927-1938.

浅沼俊輔・二戸奈央子・大川泰一郎・平沢 正（2008）水稲品 種ササニシキとハバタキの収量, 乾物生産とこれに関わる 生理生態的性質の比較. 日作紀 77: 474-480.

Bailey, L.H. (1896) Evolution of the Petunia. In "The Survival of the Unlike", MacMillan, 465-472.

Deguchi, A., S. Ohno, M. Hosokawa, F. Tatsuzawa and M. Doi (2013) Endogenous post-transcriptional gene silencing of flavone synthase resulting in high accumulation of anthocyanins in black dahlia cultivars. Planta 237: 1325-1335.

Fekih, R., H. Takagi, M. Tamiru, A. Abe, S. Natsume, H. Yaegashi, S. Sharma, S. Sharma, H. Kanzaki, H. Matsumura et al. (2013) MutMap+: genetic mapping and mutant identification without crossing in rice. PLoS One 8: e68529.

Koseki, M., K. Goto, C. Masuta and A. Kanazawa (2005) The startype color pattern in Petunia hybrida 'Red Star' flowers is induced by sequence-specific degradation of chalcone synthase RNA. Plant Cell Physiol. 46: 1879-1883.

Mann, C.C. (1999) Crop scientists seek a new revolution. Science 283: 310-314.

Morita, Y., R. Saito, Y. Ban, N. Tanikawa, K. Kuchitsu, T. Ando, M. Yoshikawa, Y. Habu, Y. Ozeki and M. Nakayama (2012) Tandemly arranged chalcone synthase $A$ genes contribute to the spatially regulated expression of siRNA and the natural bicolor floral phenotype in Petunia hybrida. Plant J. 70: 739-749. 
Napoli, C., C. Lemieux and R. Jorgensen (1990) Introduction of a chimeric chalcone synthase gene into petunia results in reversible co-suppression of homologous genes in trans. Plant Cell 2: 279-289.

Ohno, S., M. Hosokawa, M. Kojima, Y. Kitamura, A. Hoshino, F. Tatsuzawa, M. Doi and S. Yazawa (2011) Simultaneous posttranscriptional gene silencing of two different chalcone synthase genes resulting in pure white flowers in the octoploid dahlia. Planta 234: 945-958.

Takagi, H., A. Uemura, H. Yaegashi, M. Tamiru, A. Abe, C. Mitsuoka, H. Utsushi, S. Natsume, H. Kanzaki, H. Matsumura et al. (2013a) MutMap-Gap: whole-genome resequencing of mutant F2 progeny bulk combined with de novo assembly of gap regions identifies the rice blast resistance gene Pii. New Phytol. 200: 276-283.

Takagi, H., A. Abe, K. Yoshida, S. Kosugi, S. Natsume, C. Mitsuoka,
A. Uemura, H. Utsushi, M. Tamiru, S. Takuno et al. (2013b) QTL-seq: rapid mapping of quantitative trait loci in rice by whole genome resequencing of DNA from two bulked populations. Plant J. 74: 174-183.

高橋 有 - 山内卓樹 - 角井宏行 - 寺内良平 - 大柳 一 - 小宮怜 奈・宮武宏治・内藤 健 (2013) 次世代の遺伝学々育種. 育種学研究 15: 115-121.

Takai, T., S. Adachi, F. Taguchi-Shiobara, Y. Sanoh-Arai, N. Iwasawa, S. Yoshinaga, S. Hirose, Y. Taniguchi, U. Yamanouchi, J. Wu et al. (2013) A natural variant of NAL1, selected in highyield rice breeding programs, pleiotropically increases photosynthesis rate. Sci. Rep. 3: 2149.

Yamamoto, T., J. Yonemaru and M. Yano (2009) Towards the understanding of complex traits in rice: substantially or superficially? DNA Res. 16: 141-154.

\section{当日 演題}

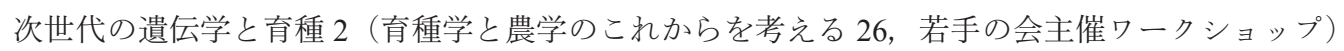

企画者: 高橋 有 ${ }^{1,2}$, 山内卓樹 2,3 , 内藤 健 $^{1}$ (1. 農業生物資源研究所, 2. 日本学術振興会特別研究員 PD, 3 . 名大 院生命農学)

1. 花き園芸植物研究から明らかになった花色制御機構 森田裕将（香川大学農学部）

2. 自然変異の利用によるイネ個葉光合成能力の遺伝的改良 安達俊輔 1,2 (1. 農業生物資源研究所，2. 日本学術振興会特別研究員 PD)

3. MutMap, MutMap+\& MutMap-Gap: 次世代シーケンサーを用いた遺伝子単離技術 高木宏樹 ${ }^{1,2}$, 八重樫弘樹 ${ }^{1}$, 植村亜衣子 ${ }^{1}$, 宇津志博恵 ${ }^{1}$, 夏目 俊 ${ }^{1,2}$, 阿部 陽 ${ }^{1}$, 寺内良平 ${ }^{1,2}$ (1. 岩手生物工学研 究センター，2．岩手大院連合農学） 